\title{
O SIGILO DE DADOS BANCÁRIOS NO BRASIL, ONTEM E HOJE: ENTRE O DIREITO À INTIMIDADE E O DEVER DE COMPARTILHAMENTO
}

\author{
BANK SECRECY IN BRAZIL, YESTERDAY AND TODAY: BETWEEN THE RIGHT \\ TO PRIVACY AND THE DUTY TO SHARE
}

Recebido: 07.04.2020

Aprovado: 14.03 .2020

\author{
Bruno Freire de Carvalho Calabrich \\ Doutorando em Direito pela UnB. Mestre em \\ Direitos e Garantias Fundamentais pela FDV. \\ MBA em Gestão Pública pela FGV. Procurador \\ Regional da República. \\ EMAIL: brunocalabrich@hotmail.com \\ LATTES: http://lattes.cnpq.br/7471416575819894 \\ ORCID: https:/ / orcid.org/0000-0002-9018-5066
}

\author{
Pablo Coutinho Barreto \\ Mestre em Desenvolvimento e Meio Ambiente \\ pela Universidade Federal de Sergipe. \\ Especialista em Direito Civil pela Fundação \\ Faculdade de Direito da Bahia. Procurador da \\ República. \\ EMAIL: pablocbarreto@gmail.com \\ LATTES: http://lattes.cnpq.br/5776952907030158 \\ ORCID: https:/ / orcid.org/0000-0002-3126-0310
}

RESUMO: O estudo aborda o sigilo bancário, sua conceituação, sua extensão e, especialmente, sua evolução nos planos positivo-normativo e jurisprudencial brasileiros, até o momento atual. Para tanto, ampara-se em pesquisa bibliográfica e documental, com destaque para o tratamento constitucional e legal do sigilo bancário ao longo dos anos e as principais decisões do Supremo Tribunal Federal sobre o tema. A problematização proposta tem como foco a controvérsia, ainda não superada, a respeito da prescindibilidade de prévia autorização judicial para acesso aos dados bancários por autoridades do Estado.

PALAVRAS-CHAVE: privacidade; sigilo bancário; reserva jurisdicional.

\begin{abstract}
The study addresses the bank data confidentiality, its concept, its extension and, especially, the evolution of the theme in the Brazilian positivenormative and jurisprudential plans, until the present moment. Therefore, it relies on bibliographic and documentary research, with emphasis on the constitutional and legal treatment of bank data confidentiality over the years and the main decisions of the Brazilian Supreme Court on the subject. The proposed problematization focuses on the controversy, which has not yet been overcome, regarding the need for prior judicial authorization for access to bank data by State authorities.
\end{abstract}

KEY WORDS: privacy; bank data confidentiality; jurisdictional reserve.

SUMÁRIO: 1 Introdução 2 Conceito e fundamentos do sigilo bancário 3 Um rápido sobrevoo no direito comparado: o sigilo bancário em outros países 4 A evolução do sigilo bancário no Brasil: do segredo absoluto ao sigilo moderado 5 A Constituição Federal de 1988 e a Lei Complementar no 105/2001 como novos paradigmas 6 O acesso direto por força de disposição legal como regra - dever de compartilhamento -

55 | Revista do Programa de Pós-Graduação em Direito da UFBA, e-issn 2358-4777, v. 30, n. 01, p.55 -77, Jan-Jun 2020 
e a reserva jurisdicional como exceção 7 O sigilo bancário e o Ministério Público: uma questão a ser resolvida 8 Conclusões 9 Referências

\section{Introdução}

O sigilo bancário, compreendido como um atributo decorrente da obrigação de proteção dos dados sobre operações bancárias custodiados pelas instituições financeiras, está associado ao próprio surgimento dos bancos e ao interesse de se preservar os detalhes dos negócios comerciais por estes entabulados do escrutínio de terceiros estranhos a estas relações.

Ocorre que, para fazer frente às suas diversas competências constitucionais e para evitar que a prática de crimes seja acobertada pelo abuso do direito à confidencialidade das informações bancárias, o Estado precisa ter acesso a esses dados.

O tratamento conferido ao sigilo bancário na legislação estrangeira e no ordenamento jurídico brasileiro não é uniforme. Os países adotam níveis de proteção diferenciados entre si e, ao longo do tempo, a legislação brasileira passou por diversas mudanças, transitando do sigilo absoluto a um segredo moderado, o que impactou diretamente a aplicação desse instituto jurídico pelos Tribunais.

O presente artigo busca esclarecer se o sigilo bancário, enquanto reflexo econômico do direito à intimidade, pode ser flexibilizado diante de outros interesses de ordem pública, em quais situações fáticas a superação do sigilo bancário pode ocorrer e qual o procedimento adequado para tanto, notadamente se o acesso pode ocorrer diretamente por agentes públicos ou se isso demandaria uma prévia autorização do Poder Judiciário.

O texto aborda o conceito e os fundamentos do sigilo bancário, como o sigilo bancário é tratado na legislação de outros países, a evolução legislativa e jurisprudencial sobre o tema, a relação entre reserva de jurisdição e sigilo bancário, a jurisprudência atual do STF e, por fim, sigilo bancário e Ministério Público. A pesquisa empreendida tem cunho eminentemente descritivo, sem descurar da problematização concernente à necessidade de prévia autorização judicial para acesso aos dados bancários por determinadas autoridades do Estado, questão não inteiramente sedimentada pelo Supremo Tribunal Federal.

Para atingir o desiderato deste artigo recorreu-se à revisão bibliográfica de obras tradicionais da dogmática do direito tributário e também de autores atuais, bem como à pesquisa documental de textos legislativos do final do século XIX até a data presente e à análise da jurisprudência do Supremo Tribunal Federal ao longo do tempo.

\section{Conceito e Fundamentos do Sigilo Bancário}

A discrição que envolve o conteúdo das operações bancárias está associada ao próprio surgimento dos bancos e ao interesse de se preservar os detalhes dos negócios comerciais por eles entabulados do escrutínio de terceiros estranhos a estas relações.

O sigilo das informações bancárias é um atributo essencial à atividade das instituições financeiras. Para Covello (2001), os bancos têm a obrigação de não revelar, salvo justa causa, informações que venham a obter em virtude de sua atividade profissional. O sigilo bancário importaria, segundo Labanca (1968), em um dever de silêncio a cargo dos bancos a respeito de fatos vinculados com pessoas com quem mantêm

56 | Revista do Programa de Pós-Graduação em Direito da UFBA, e-issn 2358-4777, v. 30, n. 01, p.55 -77, Jan-Jun 2020 
relações comerciais. Nas palavras de Malagarrica (1970), o dever de sigilo é a obrigação imposta aos bancos de não revelar a terceiros, sem justa causa, os dados referentes a seus clientes que tenham conhecimento como consequência das relações jurídicas que os vinculam.

Podemos, assim, conceituar o sigilo bancário como a obrigação de proteção dos dados relacionados a operações bancárias custodiados pelas instituições financeiras.

Diversas são as teorias que buscam explicar os fundamentos jurídicos do sigilo dos dados bancários. Dentre estas, Chinen (2005) e Cavalcante (2007) destacam sete principais: teoria contratualista; teoria da responsabilidade civil; teoria da boa-fé; teoria consuetudinária; teoria legalista; teoria do segredo profissional; e teoria do direito à intimidade.

A teoria contratualista parte da ideia de que o sigilo bancário decorre de uma convenção pactuada entre o banco e o cliente por meio de um contrato bancário. Ainda que não prevista expressamente, a discrição em relação aos dados das operações bancárias seria uma cláusula implícita, que imputaria uma obrigação acessória à instituição financeira.

Também conhecida como teoria delitual ou do ato ilícito, para a teoria da responsabilidade civil, o sigilo bancário decorreria do dever geral de não prejudicar terceiros, sob pena de reparação do dano. Assim, haveria o interesse do cliente na manutenção do sigilo das informações bancárias, cuja revelação importaria em um dano.

A teoria da boa-fé ou do dever de lisura aponta como fundamento a confiança e a lealdade que os contratantes devem observar na execução da avença, sendo a obrigação de manutenção do sigilo uma especificidade do dever de boa-fé e lisura nos contratos bancários.

Para a teoria consuetudinária, o dever de sigilo dos dados bancários fundamentase nos usos e costumes universalmente aceito pelos bancos de manter reserva sobre os negócios de seus clientes, uma vez que as atividades bancárias se caracterizariam pela relação de fidúcia que rege a relação contratual.

A teoria legalista aponta como fundamento do sigilo bancário a existência de lei que o discipline, resultado da evolução das práticas comerciais que enlaçam cliente e banco em uma relação fiduciária.

A teoria do segredo profissional busca atribuir fundamento ao sigilo bancário com apoio em normas de natureza eminentemente penal, que tutelam situações em que se mostra obrigatória o dever de confidência, tal como ocorre na relação médico /paciente e advogado/cliente. Assim, qualifica o sigilo bancário como uma espécie do dever de sigilo profissional.

Por fim, destaca-se a teoria do direito da personalidade ou do direito à intimidade, que encontra no sigilo dos dados bancários uma expressão do direito à privacidade, um direito da personalidade, com sede constitucional, de titularidade do cliente.

No Brasil, a doutrina, majoritariamente, acolhe a teoria do direito à intimidade como fundamento para o sigilo dos dados bancários, que se prestaria a tutelar o viés econômico da vida privada dos cidadãos.

Neste sentido, Arnold Wald (1998) sustenta que o sigilo bancário é o meio para resguardar a privacidade no campo econômico, pois veda a publicidade sobre a movimentação da conta-corrente bancária e das aplicações financeiras. Para Ives Gandra da Silva Martins (2001), o sigilo bancário é uma defesa da privacidade, que não diz respeito apenas a aspectos íntimos, mas também a externalidade, como, por exemplo, os dados patrimoniais. Melina Flores (2019), por sua vez, esclarece, de forma objetiva, que a reserva 
das informações referentes ao sigilo bancário ou financeiro emerge como manifestação do direito fundamental à vida privada dos cidadãos e encontra-se estabelecida no artigo 5으, inciso X, da Constituição da República de 1988.

Identificado o fundamento jurídico para se conferir proteção aos dados de operações bancárias, no ordenamento jurídico brasileiro, convêm seguir a análise de modo a precisar a extensão do sigilo bancário.

A conformação do segredo sustentada por Wald (1998) abrange todos os aspectos da relação entre o banco e o cliente, presumindo-se a vontade do cliente de manter o sigilo em relação à sua conta bancária, salvo autorização em contrário. Farhat (1980) segue na mesma linha, apenas ressaltando não estarem incluído no âmbito de proteção os fatos que o banqueiro teve conhecimento por força de uma relação externa aos negócios bancários.

Para Labanca (1968) e para Malagarrica (1970), o objeto de proteção abrangeria os fatos da relação comercial entre o sujeito ativo e o passivo, ou seja, seria formado pelos dados obtidos pelo banco em razão das relações jurídicas mantidas com seus clientes.

Sérgio Covello (2001) aprofunda melhor a questão, precisando os contornos do sigilo bancário. Identifica como estando dentro do âmbito de proteção do dever de confidência as operações bancárias (ativas, passivas e serviços em geral), dados dessas operações (forma de pagamento, montante, destinação etc), dados informados pelo cliente para conseguir a operação (dados pessoais, endereço, estado civil, nome do cônjuge, ordenado, local de trabalho, relação de bens, e outros dados íntimos da vida particular do cliente que chegam ao conhecimento do banco em virtude da operação realizada.

Segundo Michel Haber Neto (2018), o sigilo bancário apresenta ao menos duas perspectivas: num primeiro plano, busca proteger a privacidade daqueles dados relativos ao contribuinte que já se encontram na posse da administração tributária; num segundo plano, visa a impedir que a administração tributária tenha acesso a informações privadas do contribuinte sem seu consentimento ou sem respeitar o procedimento adequado.

No Brasil, o âmbito de proteção do sigilo bancário foi delimitado inicialmente pela Lei no 4.595/1964, que dispôs, em seu artigo 38, o dever das instituições financeiras conservarem o sigilo em suas operações ativas e passivas e serviços prestados, no que foi secundada pela Lei Complementar no 105/2001 ${ }^{1}$, atualmente em vigência.

Acertadamente, o Superior Tribunal de Justiça decidiu, no ano de 2018, ao julgar o Recurso Especial no 1.561.191/SP², que os dados cadastrais bancários (informações de seus correntistas tais como número da conta-corrente, nome completo, RG, CPF, número de telefone e endereço) estão incluídos na definição de dados cadastrais e não estão, portanto, protegidos por sigilo bancário, que abriga apenas os serviços da conta (aplicações, transferências, depósitos e etc):

PROCESSUAL CIVIL. AÇÃO CIVIL PÚBLICA. LEGITIMIDADE DO MINISTÉRIO PÚBLICO. FORNECIMENTO DE DADOS CADASTRAIS DE CLIENTES DE INSTITUIÇÕES FINANCEIRAS MEDIANTE REQUISIÇÃO DIRETA DO PARQUET OU DA POLÍCIA FEDERAL. DIREITOS DIFUSOS E COLETIVOS CARACTERIZADOS. SEGURANÇA PÚBLICA. ACESSO A DADOS CADASTRAIS. POSSIBILIDADE. HISTÓRICO DA DEMANDA.

\footnotetext{
${ }^{1}$ Art. 1ํ As instituições financeiras conservarão sigilo em suas operações ativas e passivas e serviços prestados.

2 STJ, 2a T., REsp 1561191/SP, Rel. Ministro HERMAN BENJAMIN, Data de julgamento: 19.04.2018, Data de publicação: DJe 26.11.2018.
}

58 | Revista do Programa de Pós-Graduação em Direito da UFBA, e-issn 2358-4777, v. 30, n. 01, p.55 -77, Jan-Jun 2020 


\section{[...]}

5. Outro ponto imprescindível ao deslinde da presente controvérsia é a distinção de dados e dados cadastrais. Enquanto os "dados" revelam aspectos da vida privada ou da intimidade do indivíduo e possuem proteção constitucional esculpida no art. 5으, X e XII, da Constituição Federal, os "dados cadastrais" se referem a informações de caráter objetivo que todos possuem, não permitindo a criação de qualquer juízo de valor sobre o indivíduo a partir de sua divulgação. São essencialmente um conjunto de informações objetivas fornecidas pelos consumidores/clientes/usuários sistematizadas em forma de registro de fácil acesso por meio de seu armazenamento em banco de dados de pessoas jurídicas de direito público ou privado, contendo informações como nome completo, CPF, RG, endereço, número de telefone etc. 6 . O Supremo Tribunal Federal consolidou jurisprudência de que o conceito de "dados" previsto na Constituição é diferente do de "dados cadastrais". Somente aquele tem assegurada a inviolabilidade da comunicação de dados. A propósito: STF, RE 418.416/SC, Rel. Min. Sepúlveda Pertence, Tribunal Pleno, DJ 19.12.2006; STF, HC 91.867/PA, Rel. Min. Gilmar Mendes, Segunda Turma, DJe 19.9.2012, publicado em 20.9.2012. 7. Os dados cadastrais bancários (informações de seus correntistas tais como número da conta-corrente, nome completo, RG, CPF, número de telefone e endereço) estão incluídos na definição de dados cadastrais e não estão, portanto, protegidos por sigilo bancário, que abriga apenas os serviços da conta (aplicações, transferências, depósitos e etc) e não os dados cadastrais de seus usuários. 8. Ressalte-se que o STJ, ao apreciar controvérsia referente ao acesso a dados cadastrais telefônicos, adotou o mesmo entendimento aqui esposado, ao consignar que informações referentes ao proprietário de linha telefônica (nome completo, CPF, RG, número da linha e endereço) buscam somente a identificação de seus usuários e, portanto, não estão acobertadas pelo sigilo das comunicações telefônicas. Nesse sentido: RHC 82.868/MS, Rel. Ministro Felix Fischer, Quinta Turma, DJe 1․8.2017; HC 131.836/RJ, Rel. Ministro Jorge Mussi, Quinta Turma, DJe 6.4.2011. [...]

Deste modo, amparado na legislação vigente, na jurisprudência dos Tribunais Superiores e na doutrina, é possível delimitar de forma precisa que o alcance do sigilo bancário compreende as operações ativas e passivas e os serviços das instituições financeiras, a exemplo de informações acerca de saldos em conta-corrente ou aplicações, extratos ou detalhamento de movimentações financeiras. Não estão protegidos por sigilo bancário, todavia, os dados cadastrais bancários, tais como número da conta-corrente, nome completo, documentação pessoal, número de telefone e endereços físicos e eletrônicos do respectivo titular, RG e CPF, dentre outros, estão incluídos na definição de dados cadastrais e não estão, portanto, que abriga apenas os serviços da conta (aplicações, transferências, depósitos e etc) e não os dados cadastrais de seus usuários. 


\section{Um Rápido Sobrevoo no Direito Comparado: O Sigilo Bancário em Outros Países}

Para uma análise criteriosa da conformação do sigilo bancário no direito brasileiro mostra-se necessário recorrer a uma revisão do tratamento que the é conferido pelos diversos ordenamentos jurídicos estrangeiros, uma vez que a reserva das informações custodiadas pelas instituições financeiras em relação às operações de seus clientes é um fato inerente às atividades desenvolvidas pelas instituições financeiras.

Como bem afiançado por René David (1986), o jurista deve interessar-se pelo direito comparado, seja para melhor compreender o seu próprio direito, seja para tentar aperfeiçoá-lo, ou ainda, para estabelecer regras de conflito ou uma harmonização dos diversos direitos. Assim, para que o direito comparado cumpra sua função, é necessário deixar de se concentrar unicamente no estudo do direito nacional, e fazer uso do método comparativo.

Cavalcante (2007), ao se debruçar sobre o direito comparado, buscou agrupar os sistemas jurídicos de acordo com o âmbito de proteção conferido às informações bancárias, classificando-os em países que adotam sigilo absoluto, sigilo reforçado e sigilo moderado.

Os sistemas jurídicos que adotam o sigilo "absoluto" são próprios dos denominados paraísos fiscais ${ }^{3}$, dentre os quais podem ser citados os seguintes países e territórios autônomos: Comunidade das Bahamas, Ilhas Cayman, Hong Kong, Mônaco, Liechtenstein, cujas legislações facilitam a circulação de capital, ao assegurar o anonimato dos titulares das respectivas operações bancárias.

O denominado sigilo reforçado está presente na Suíça, Áustria, Luxemburgo e Uruguai, sendo caracterizado por um número reduzido de situações que excepcionam o dever de reserva e pela presença de regras procedimentais bastante restritivas para 0 acesso a dados bancários.

Os países que adotam o sigilo bancário moderado caracterizam-se pelo enfoque à proteção do segredo por meio de norma constitucional, implícita ou explícita, regulamentada por norma legal, que especifica diversas derrogações ao dever de confidência, bem como os variados procedimentos para o acesso aos dados de operação bancárias. Nesta categorização se encontra um número relevante de países, como Argentina, Alemanha, Brasil, Estados Unidos da América, França e Portugal.

Para os fins deste artigo, mostra-se importante o detalhamento da forma de acesso aos dados bancários nos sistemas jurídicos dos países que adotam como regra o sigilo bancário moderado, de modo a melhor entender a adequação das disposições vigentes no direito brasileiro.

$\mathrm{Na}$ Argentina, o sigilo bancário encontra-se disciplinado expressamente no artigo 39 da Lei no 21.526/1977, que estabelece a proibição de divulgação dos dados financeiros por parte dos bancos, exceto quando requisitados pelos juízes em causas judiciais, pelo Banco Central no exercício de suas funções, e pelo fisco, sob determinadas condições. 0 compartilhamento dos dados bancários com a administração tributária argentina, portanto, independe de intervenção judicial, podendo ser objeto de requisição direta, desde que seja veiculada por meio de um pedido formal e prévio.

Em linha próxima, o sistema jurídico alemão faculta o compartilhamento dos dados bancários ao fisco, sem a necessidade de autorização do Poder Judiciário. Cavalcante (2007) esclarece que o sigilo bancário encontra previsão específica na Lei

\footnotetext{
${ }^{3} \mathrm{Na}$ legislação brasileira a definição de paraíso fiscal pode ser encontrada no artigo 1o da Instrução Normativa @ 1307/2010 da Secretaria da Receita Federal.
}

60 | Revista do Programa de Pós-Graduação em Direito da UFBA, e-issn 2358-4777, v. 30, n. 01, p.55 -77, Jan-Jun 2020 
Bancária de 1961, entretanto a jurisprudência da Suprema Corte Alemã tem admitido a ponderação de interesses em face do direito à intimidade, viabilizando o acesso da administração tributária diretamente às informações bancárias. O acesso é facultado diante da negativa do contribuinte em fornecê-las, porém não se faculta à administração tributária da Alemanha o acesso periódico aos dados das operações bancárias.

Nos Estados Unidos da América, desde a edição do Bank Secrecy Act, nos idos de 1970, os bancos passaram a ser obrigados a fornecer informações ao tesouro americano em caso de transações suspeitas de envolvimento com atividades ilegais, ou qualquer operação cujo montante ultrapassasse 10.000 dólares. Chinen (2005) recorda que, submetido ao crivo da Suprema Corte Americana, entendeu-se que esse acesso direto pelo Internal Revenue Service - IRS não violava a 4a Emenda, abrindo-se caminho para acesso irrestrito aos dados bancários mediante intimações administrativas.

Com a edição do Right to Financial Privacy Act, em 1978, que regula as condições de acesso a dados privados de natureza financeira pelos poderes públicos, o cliente deve ser notificado em caso de demanda por seus dados bancários, com direito a protestar contra essa requisição, mas sem conseguir opor tal prerrogativa aos governos estaduais e à administração tributária americana.

Na França, a regulamentação legal do sigilo bancário data do início do século XVIII (Réglement d'octobre 1706), que reconhecia a necessidade de segredo nos negócios bancários, cambiais, comerciais e financeiros. Entretanto, o direito à confidência das informações bancárias encontra limites no interesse do Estado, tendo o fisco francês o acesso direto a dados bancários, seja por comunicação espontânea, seja por requisição direta de informações.

O sistema jurídico português admite, desde o ano 2000, com a aprovação da Lei da Reforma de Tributação do Rendimento, o acesso direto pelo fisco aos documentos bancários, ampliando as exceções ao sigilo bancário previstas no Decreto Lei $n^{\circ}$ 298/92, que dispõe sobre o Regime Geral das Instituições de Crédito e Instituições Financeiras.

Como se pode perceber do tratamento jurídico conferido ao sigilo bancário pelos diversos sistemas jurídicos apontados, dentre os países integrantes da Organização para a Cooperação e Desenvolvimento Econômico - OCDE, somente Suíça, Áustria e Luxemburgo adotam o sigilo reforçado, não admitindo o acesso direto a dados bancários, em determinadas situações, por órgãos públicos.

Essa convergência dos normativos internos de diversos países em relação ao conteúdo das recomendações expedidas pela OCDE se explica pela percepção da imprescindibilidade de se combater os crimes de terrorismo, tráfico de armas e de pessoas, evasão e fraude fiscais, lavagem de dinheiro e corrupção de agentes públicos.

Assim, adverte Chinen (2005), a OCDE preocupa-se com a possibilidade de os contribuintes esconderem atividades ilegais e escaparem da tributação, opondo o sigilo bancário às autoridades governamentais, provocando consequências danosas, local e internacionalmente, embora reconheça a importância e legitimidade do sigilo bancário como instrumento de proteção do sigilo dos negócios financeiros dos indivíduos e empresas.

\section{A Evolução do Sigilo Bancário no Brasil: Do Segredo Absoluto ao Sigilo Moderado}

Nos idos do Século XIX, os dados bancários, no Brasil, estavam protegidos por um sigilo absoluto. $O$ acesso a dados de operações bancárias e comerciais não era lícito às autoridades públicas, por expressa determinação do artigo 17 do Código Comercial (Lei no

61 | Revista do Programa de Pós-Graduação em Direito da UFBA, e-issn 2358-4777, v. 30, n. 01, p.55 -77, Jan-Jun 2020 
$556 / 1850)^{4}$. A reserva era ampla e abarcava inclusive a exibição de informações e livros comerciais por ordem judicial, à exceção de casos específicos relacionados à sucessão, disputas societárias e falência ${ }^{5}$.

Oliveira (2001) aponta que as disposições constantes no Código Comercial conduzem ao entendimento de que somente em casos excepcionais os contribuintes teriam a obrigatoriedade de exibir seus livros a outrem, mediante ordem judicial.

A mitigação do sigilo bancário tem seu início, de maneira gradual, por meio de avanços normativos que buscavam viabilizar à autoridade tributária instrumentos para fiscalizar e cobrar o imposto sobre a renda instituído no começo da década de 1920.

A Lei $n$ o 4.230/1920 autorizou o governo federal a instituir um imposto sobre rendas e a expedir a regulamentação necessária para a sua arrecadação e fiscalização. No ano seguinte, foi editado o Decreto no 14.729/1921 que obrigava as Inspetorias dos Bancos a fornecerem às repartições arrecadadoras os esclarecimentos que lhes forem solicitados para auxiliar a inscrição ou lançamento do imposto sobre a renda ${ }^{6}$.

Os regulamentos dos impostos sobre a renda que sucederam o Decreto no 14.729/1921, de igual forma, dispunham sobre a obrigação de prestar as informações solicitadas pela administração tributária, destacando-se o Decreto № 17.390/1926, que estabelecia, de forma expressa, o dever dos estabelecimentos bancários prestarem as informações relativas aos rendimentos de capitais mobiliários, em casos concretos, mediante solicitação especial do encarregado do lançamento ${ }^{7}$, e o Decreto no 21.554/1932, que acresceu aos bancos a obrigação de prestar informação de todos os juros pagos ou creditados a particulares, acima de determinado valor, indicando endereço da pessoa a que pertenciam, e junho ${ }^{8}$.

Até o final da década de 1930, o acesso aos dados de operações bancárias por agentes do fisco somente possuía previsão expressa os regulamentos dos impostos sobre a renda, possibilitando ao contribuinte arguir a proibição contida no artigo 17 do Código Comercial como uma forma de se opor à fiscalização do Serviço de Arrecadação do Imposto de Renda.

\footnotetext{
${ }^{4}$ Art. 17 - Nenhuma autoridade, juízo ou tribunal, debaixo de pretexto algum, por mais especioso que seja, pode praticar ou ordenar alguma diligência para examinar se o comerciante arruma ou não devidamente seus livros de escrituração mercantil, ou neles tem cometido algum vício.

${ }^{5}$ Art. 18 - A exibição judicial dos livros de escrituração comercial por inteiro, ou de balanços gerais de qualquer casa de comércio, só pode ser ordenada a favor dos interessados em gestão de sucessão, comunhão ou sociedade, administração ou gestão mercantil por conta de outrem, e em caso de quebra.

${ }^{6}$ Art. 43. Compete á fiscalização do imposto.

[...]

d) as Camaras Syndicaes dos Corretores, aos tabelliães, Inspectoria de Seguros, á Inspectoria de Bancos, á Super-intendencia de Clubs, escrivães officiaes do registro de immoveis, obrigados todos a fornecer ás repartições arrecadadoras os esclarecimentos que lhes forem solicitados para auxiliar a inscripção ou lançamento dos impostos;

7 Art. 79. Os estabelecimentos bancarios prestarão as informações relativas aos rendimentos classificados na 2a categoria, em casos concretos, mediante solicitação especial do encarregado do lançamento (Circular n. 67, e 27 de novembro de 1924, do ministro da Fazenda).

${ }^{8}$ Art. 10 [...]

Art. 79. Substituir pelo seguinte:

Os estabelecimentos bancários prestarão, até 30 de junho, informação de todos os juros pagos ou creditados a particulares, que excederem de 1:000\$0 com as indicações do endereço da pessoa a que pertencem. As informações de juros inferiores a essa quantia só serão prestadas mediante exigência da autoridade fiscal, em casos concretos.
}

62 | Revista do Programa de Pós-Graduação em Direito da UFBA, e-issn 2358-4777, v. 30, n. 01, p.55 -77, Jan-Jun 2020 
Esse cenário legislativo foi alterado com a vigência do Decreto-Lei no 1.168/1939', que autorizou aos funcionários do imposto de renda, mediante ordem escrita do diretor do Imposto e dos chefes de Secções nos Estados, examinarem a escrita comercial dos contribuintes, revogando, de forma expressa, a vedação disposta no artigo 17 do Código Comercial, em relação às iniciativas de fiscalização da administração tributária.

O Decreto-Lei no 5.884/1943, por sua vez, incorporou o dever dos estabelecimentos bancários prestarem as informações sobre os juros pagos ou creditados a particulares, com a respectiva indicação de titularidade das contas-correntes ${ }^{10}$, obrigação que foi mantida com a edição da Lei no 3.470/1958.

$\mathrm{O}$ acesso direto das informações bancárias pelo fisco foi levado ao crivo do Supremo Tribunal Federal, pela primeira vez em 1966, no julgamento do Recurso Ordinário em Mandado de Segurança no 19.925/GB ${ }^{11}$, que decidiu não ser o sigilo bancário oponível ao fisco, uma vez que haveria o dever de manutenção do segredo pelos agentes da administração tributária, consoante disposição expressa nos artigos 200 e 201 do Decreto no 4.373/1959.

Em sentido diverso, entretanto, entendeu o Supremo Tribunal Federal no julgamento do Agravo de Instrumento no $40.883 / \mathrm{GB}^{12}$, ao afirmar que somente a partir da vigência da Lei no 4.154/1962 a obrigação de prestar informações sobre as operações de seus clientes alcançou os estabelecimentos bancários.

A Lei $n$ ㅇ 4.154/1962 ${ }^{13}$ dispôs que os estabelecimentos bancários não poderiam eximir-se de fornecer à fiscalização do imposto de renda extratos de contas-correntes de seus clientes, nem informações ou quaisquer esclarecimentos solicitados, vindo a afastar quaisquer dúvidas sobre a obrigação de compartilhamento de dados bancários diretamente com a administração tributária e cristalizando o modelo de sigilo bancário moderado no Brasil.

Reforçaram o perfil moderado do instituto do sigilo bancário no direito brasileiro, admitindo o compartilhamento de dados bancários com a administração tributária, sem a

\footnotetext{
${ }^{9}$ Art. 14. Os peritos e funcionários do imposto de renda. mediante ordem escrita do diretor do Imposto e dos chefes de Secções nos Estados, poderão proceder a exame na escrita comercial dos contribuintes, para verificarem a exatidão de suas declarações e balanços.

$\S 1$ 10 A recusa de exibição dos livros dará lugar à imposição, por aquelas autoridades, de multa de 5:000\$000 a 20:000\$000, promovendo-se, em seguida, a exibição judicial.

$\S 2$ O Os infratores terão o prazo de 30 dias para se defenderem perante a autoridade administrativa de 1 a instância.

§ 30 Para os efeitos do presente artigo, fica revogado o disposto no art. 17 do Código Comercial.

${ }^{10}$ Art. 110. O Banco do Brasil e demais estabelecimentos bancários, inclusive as Caixas Econômicas, deverão prestar informações de todos os juros que excederem a $\operatorname{Cr} \$ 1.000,00$, pagos ou creditadas a particulares, com indicação dos nomes e endereços das pessoas a que pertencerem.

Parágrafo único. As informações de juros inferiores a essa quantia, bem como os das contas correntes relativas ao comércio, serão prestadas quando exigidas pela autoridade lançadora.

${ }^{11}$ SIGILO BANCÁRIO. AGENTES DO IMPOSTO DE RENDA. AÇÃO FISCAL NOS BANCOS. RECURSO NÃO PROVIDO. (STF, 3a T., RMS 15925, Relator: Min. GONÇALVES DE OLIVEIRA, Data de julgamento: 20.05.1966, Data de publicação: DJ de 24.06.1966).

12 PROCEDIMENTO FISCAL. SIGILO BANCÁRIO. APLICAÇÃO DA LEI VIGENTE AO TEMPO DO PROCEDIMENTO. AGRAVO DESPROVIDO. (STF, 3a T., Al 40883, Relator(a): Min. HERMES LIMA, Data de julgamento: 10/11/1967, Data de publicação: DJ 08.03.1968).

${ }^{13}$ Art. 70 Os estabelecimentos bancários, inclusive as Caixas Econômicas, não poderão eximir-se de fornecer à fiscalização do impôsto de renda, em cada caso especificado em despacho do diretor, dos delegados regionais ou seccionais e dos inspetores do impôsto de renda, cópias das contas correntes de seus depositantes e de outras pessoas que tenham relações com tais estabelecimentos, nem de prestar informações ou quaisquer esclarecimentos solicitados.
}

63 | Revista do Programa de Pós-Graduação em Direito da UFBA, e-issn 2358-4777, v. 30, n. 01, p.55 -77, Jan-Jun 2020 
necessidade de intervenção judicial, dois importantes diplomas legais: a Lei no 4.595/1964 e o Código Tributário Nacional (Lei no 5.172/1966).

A Lei no $4.595 / 1964^{14}$ foi a primeira a disciplinar de forma expressa o sigilo bancário no Brasil. Previu exceções ao dever de reserva tanto em favor das autoridades fiscais, quanto em favor das comissões parlamentares de inquérito, delimitou o alcance do sigilo bancário às operações ativas e passivas e aos serviços prestados pelas instituições financeiras, dispôs sobre o acesso direto às informações bancárias pelos agentes fiscais tributários federais e estaduais, resguardou a manutenção do sigilo dos dados bancários transferidos ao fisco e inovou ao estabelecer um tipo penal específico em caso de violação do segredo.

Dois anos após, o Congresso Nacional aprovou o Código Tributário Nacional que, além de dispor sobre a inoponibilidade de sigilo à administração fazendária que pudesse limitar o exame de livros, documentos, arquivos papéis e mercadorias, reproduziu a obrigação das instituições financeiras prestarem todas as informações de que dispusessem com relação aos bens, negócios ou atividades de terceiros ${ }^{15}$.

Sob esse arcabouço normativo, o Supremo Tribunal Federal continuou firme em seu entendimento de ser inoponível à autoridade fazendária o sigilo das operações

\footnotetext{
${ }^{14}$ Art. 38. As instituições financeiras conservarão sigilo em suas operações ativas e passivas e serviços prestados.
}

$\S 1$ ㅇ As informações e esclarecimentos ordenados pelo Poder Judiciário, prestados pelo Banco Central da República do Brasil ou pelas instituições financeiras, e a exibição de livros e documentos em Juízo, se revestirão sempre do mesmo caráter sigiloso, só podendo a eles ter acesso as partes legítimas na causa, que deles não poderão servir-se para fins estranhos à mesma.

§ 2o O Banco Central da República do Brasil e as instituições financeiras públicas prestarão informações ao Poder Legislativo, podendo, havendo relevantes motivos, solicitar sejam mantidas em reserva ou sigilo.

§ 3을 As Comissões Parlamentares de Inquérito, no exercício da competência constitucional e legal de ampla investigação (art. 53 da Constituição Federal e Lei no 1579, de 18 de março de 1952), obterão as informações que necessitarem das instituições financeiras, inclusive através do Banco Central da República do Brasil.

$\S 4$ ㅇ Os pedidos de informações a que se referem os $\S \S 2$ e e 3 , deste artigo, deverão ser aprovados pelo Plenário da Câmara dos Deputados ou do Senado Federal e, quando se tratar de Comissão Parlamentar de Inquérito, pela maioria absoluta de seus membros.

§ 5 ㅇ Os agentes fiscais tributários do Ministério da Fazenda e dos Estados somente poderão proceder a exames de documentos, livros e registros de contas de depósitos, quando houver processo instaurado e os mesmos forem considerados indispensáveis pela autoridade competente.

$\S 60$ O disposto no parágrafo anterior se aplica igualmente à prestação de esclarecimentos e informes pelas instituições financeiras às autoridades fiscais, devendo sempre estas e os exames serem conservados em sigilo, não podendo ser utilizados senão reservadamente.

$\S 70$ A quebra do sigilo de que trata este artigo constitui crime e sujeita os responsáveis à pena de reclusão, de um a quatro anos, aplicando-se, no que couber, o Código Penal e o Código de Processo Penal, sem prejuízo de outras sanções cabíveis.

${ }^{15}$ Art. 195. Para os efeitos da legislação tributária, não têm aplicação quaisquer disposições legais excludentes ou limitativas do direito de examinar mercadorias, livros, arquivos, documentos, papéis e efeitos comerciais ou fiscais, dos comerciantes industriais ou produtores, ou da obrigação destes de exibi-los.

Parágrafo único. Os livros obrigatórios de escrituração comercial e fiscal e os comprovantes dos lançamentos neles efetuados serão conservados até que ocorra a prescrição dos créditos tributários decorrentes das operações a que se refiram.

Art. 197. Mediante intimação escrita, são obrigados a prestar à autoridade administrativa todas as informações de que disponham com relação aos bens, negócios ou atividades de terceiros:

[...]

II - os bancos, casas bancárias, Caixas Econômicas e demais instituições financeiras;

64 | Revista do Programa de Pós-Graduação em Direito da UFBA, e-issn 2358-4777, v. 30, n. 01, p.55 -77, Jan-Jun 2020 
bancárias. No julgamento do Recurso Extraordinário no $71.640 / \mathrm{BA}^{16}$, com apoio na doutrina de Aliomar Baleeiro, O STF decidiu que os Bancos podem ser compelidos a informa ou fornecer cópias dos borderôs dos títulos descontados e das duplicatas ou cambiais sacadas conta o contribuinte, a fim de apurar-se a exata natureza ou volume de seus negócios:

Sigilo bancário. As decisões na instância ordinária entenderam que em face do Código Tributário Nacional o segredo bancário não é absoluto. razoável inteligência do direito positivo federal, não havendo ofensa ao disposto no art. 153, par. 2, da Lei Magna, nem tão pouco negativa de vigência do art. 144 do Código Civil. 0 objetivo do writ era afastar a exigência de apresentação de fichas contábeis, ao fundamento de violação de sigilo bancário. Inocorrência de dissidio jurisprudencial. Recurso extraordinário não conhecido.

Este cenário jurisprudencial se altera com a promulgação da Constituição Federal de 1988, que causou uma turbulência no então consolidado entendimento do Supremo Tribunal Federal acerca da desnecessidade de intervenção judicial para o acesso a dados bancários pela administração tributária.

\section{A Constituição Federal de 1988 e a Lei Complementar № 105/2001 como Novos Paradigmas}

A discussão sobre a possibilidade do acesso direto ou sobre a necessidade de autorização do Poder Judiciário para que a administração tributária obtivesse as informações bancárias abrangidas pelo sigilo renova-se com a Constituição Federal de 1988, que dispôs, expressamente, acerca da inviolabilidade da intimidade e da vida privada como um direito fundamental.

O art. 5ำ, inciso X, da Constituição Federal de 1998 afirma que são invioláveis a intimidade, a vida privada, a honra e a imagem das pessoas - de onde a doutrina e jurisprudência passam a extrair a fundamentação do sigilo bancário. Ao mesmo tempo, o art. 145, parágrafo único, da $\mathrm{CF} / 88$ faculta à administração tributária identificar, respeitados os direitos individuais e nos termos da lei, o patrimônio, os rendimentos e as atividades econômicas do contribuinte.

Na sequência, é editada a Lei Complementar (LC) n.o 105/2001 prevendo, em seu art. 5o, caber ao Poder Executivo disciplinar os critérios segundo os quais as instituições financeiras informarão à administração tributária da União as operações financeiras efetuadas pelos usuários de seus serviços. Esse artigo é hoje regulamentado pelo decreto no 4.489, de 28 de novembro 2002, que estatui as obrigações das instituições financeiras e delimita a forma pela qual as informações devem ser encaminhadas ao fisco.

As operações financeiras a serem informadas à administração tributária estão discriminadas no parágrafo 1 o do mesmo artigo 5o da LC n.o $105 / 2001^{17}$. Como requisito

\footnotetext{
${ }^{16}$ STF, 1ạ T., RE 71640, Relator: Min. DJACI FALCÃO, Data de julgamento: 17.09.1971, Data de publicação: DJ 12.11.1971.

${ }^{17}$ Art. 5o: [...]

§ 1으 Consideram-se operações financeiras, para os efeitos deste artigo: I - depósitos à vista e a prazo, inclusive em conta de poupança; II - pagamentos efetuados em moeda corrente ou em cheques; III -

65 | Revista do Programa de Pós-Graduação em Direito da UFBA, e-issn 2358-4777, v. 30, n. 01, p.55 -77, Jan-Jun 2020
} 
para o acesso às informações sobre os contribuintes, o art. 60 do mesmo diploma legal prevê que as autoridades e os agentes fiscais tributários somente poderão examinar documentos, livros e registros de instituições financeiras quando houver processo administrativo instaurado ou procedimento fiscal em curso e quando tais exames sejam considerados indispensáveis pela autoridade administrativa competente.

Conforme discorre Erik Grasmtrup (2014), a definição legal de instituição financeira da Lei Complementar no 105 aproxima-se da chamada lei de reforma bancária (Lei no 4.595/1964). O primeiro diploma preferiu a técnica da enumeração, e o segundo conceituou-as como pessoas jurídicas que coletam, intermedeiam ou aplicam recursos financeiros próprios ou de terceiros, bem como custodiam valores. A Lei no 4.595 já determinava o sigilo nas operações ativas e passivas, ressalvada requisição judicial, de Comissão Parlamentar de Inquérito ou da fiscalização tributária, e criminalizava a conduta de quebra de sigilo, cominando a pena de reclusão, de um a quatro anos. Os destinatários da lei eram e continuam sendo sociedades empresárias cujo objeto é a intermediação do dinheiro e o depósito de recursos e valores pertencentes a terceiros.

Analisando os dispositivos da Lei Complementar n.o 105, José Paulo Baltazar Junior (2005) classifica as seguintes hipóteses de "quebra" de sigilo bancário: a) troca ou fornecimento de informações para fins privados (arts. 1, §3ㅇ, I e II); b) acesso a informações para fiscalização do sistema financeiro nacional (arts. 20 e 70); c) comunicações para fins de investigação criminal ou administrativa (arts. 1ㅇ, §3ㅇ, IV, 2으, $\S 60$ e 9o); d) informações determinadas pelo Poder Judiciário (art. 1으, §4으, 3o e 7ㅇ); e) informações e documentos necessários ao exercício do Poder Legislativo ou para investigação por Comissão Parlamentar de Inquérito (art. 4ㅇ); f) informações de interesse da fiscalização tributária (art. 1ㅇ, §3으, III; art. 5ㅇ; art. 6ㅇ); e g) informações prestadas com o consentimento do interessado (art. 1으, $\S 3, \mathrm{~V}$ ).

A possibilidade de acesso a informações bancárias ou financeiras de contribuintes é um verdadeiro poder-dever da administração tributária, mas que ao mesmo tempo está atrelado a um poder-dever de preservação do sigilo das informações recebidas. Assim é que o parágrafo único do art. 6ㅇ da LC n. $105 / 2001$ estabelece que o resultado dos exames, as informações e os documentos serão conservados em sigilo. Ademais, a "quebra" de sigilo fora das hipóteses autorizadas na LC n. 105/2001 constitui crime e sujeita os responsáveis à pena de reclusão, de um a quatro anos, e multa, aplicando-se, no que couber, o Código Penal, sem prejuízo de outras sanções cabíveis (art. 10, caput, da LC n. $105 / 2001)$.

Da mesma sorte, o Código Tributário Nacional - Lei n. 9 5.172/66 - veda a divulgação, por parte da Fazenda Pública ou de seus servidores, de informação obtida em razão do ofício sobre a situação econômica ou financeira do sujeito passivo ou de terceiros e sobre a natureza e o estado de seus negócios ou atividades (art. 198 do CTN). Excetuamse desse dever de sigilo: I - a requisição de autoridade judiciária; II - solicitações de autoridade administrativa no interesse da Administração Pública, desde que seja comprovada a instauração regular de processo administrativo por prática de infração

emissão de ordens de crédito ou documentos assemelhados; IV - resgates em contas de depósitos à vista ou a prazo, inclusive de poupança; V - contratos de mútuo; VI - descontos de duplicatas, notas promissórias e outros títulos de crédito; VII - aquisições e vendas de títulos de renda fixa ou variável; VIII - aplicações em fundos de investimentos; IX - aquisições de moeda estrangeira; X - conversões de moeda estrangeira em moeda nacional; XI - transferências de moeda e outros valores para o exterior; XII - operações com ouro, ativo financeiro; XIII - operações com cartão de crédito; XIV - operações de arrendamento mercantil; e XV - quaisquer outras operações de natureza semelhante que venham a ser autorizadas pelo Banco Central do Brasil, Comissão de Valores Mobiliários ou outro órgão competente.

66 | Revista do Programa de Pós-Graduação em Direito da UFBA, e-issn 2358-4777, v. 30, n. 01, p.55 -77, Jan-Jun 2020 
administrativa (art. 198, §1으, do CTN). Em qualquer caso, o intercâmbio de informação sigilosa no âmbito da Administração Pública será realizado de forma a assegurar a preservação do sigilo (art. 198, §1ํㅡ, do CTN).

Desse último dispositivo decorre a compreensão de que, ao compartilhar informações sigilosas com outros órgãos da Administração Pública, as autoridades fiscais não estão exatamente "quebrando" o sigilo dessas informações, que continuam a ter caráter sigiloso e nessa qualidade devem ser mantidas pela autoridade que recebe as informações compartilhadas.

Em síntese, dados bancários ou fiscais são, via de regra, sigilosos, e esse caráter não se perde quando há compartilhamento com outras autoridades do Estado. Não há nesses casos, portanto, verdadeira "quebra" do sigilo, mas sim compartilhamento do dever de preservação do caráter sigiloso dos dados repassados. A ausência de quebra, nessas hipóteses, foi um dos principais fundamentos invocados pelo STF no julgamento das ADI 2390, 2386, 2397 e 2859 e do RE 601.314 em 24.02.2016, consoante abordado adiante.

Contudo, uma melhor e mais abrangente compreensão quanto aos limites de acesso a informações bancárias e fiscais e ao dever que toca às autoridades públicas de preservação de seu sigilo exige o estudo de alguns outros dispositivos constitucionais: os incisos X, XI, XII e LXI, da Constituição Federal de 1988.

6 O Acesso Direto Por Força De Disposição Legal Como Regra - Dever De Compartilhamento - E A Reserva Jurisdicional Como Exceção

O acesso a informações sigilosas referentes a dados bancários e fiscais pode ser feito diretamente ou demandar a autorização do Poder Judiciário, sendo necessário analisar os dispositivos constitucionais previstos nos incisos $\mathrm{X}, \mathrm{XI}, \mathrm{XII}$ e $\mathrm{LXI}$, de modo a compreender qual o alcance da chamada reserva jurisdicional ${ }^{18}$ e quando a legislação ordinária autoriza o acesso direto aos referidos dados.

Advirta-se, desde logo, que não há estudos aprofundados específicos, sobre as cláusulas de reserva jurisdicional do ordenamento brasileiro, tema que costuma ser tratado apenas em manuais de direito constitucional ou em obras de direito processual penal. Quando muito, as cláusulas de reserva jurisdicional são referidas, sem maior

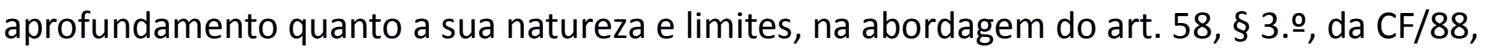
que outorga às Comissões Parlamentares de Inquérito "poderes de investigação próprios das autoridades judiciais" ${ }^{19}$.

Canotilho (2003), debruçando-se sobre o ordenamento constitucional português, aponta que a reserva de jurisdição consiste no ' 'monopólio da primeira palavra', monopólio do juiz ou reserva absoluta de jurisdição quando, em certos litígios, compete ao juiz não só a última e decisiva palavra mas também a primeira palavra referente à definição do direito aplicável a certas relações jurídicas".

\footnotetext{
${ }^{18}$ É precisa a distinção traçada pelo Ministro Teori Zavaski, em seu voto proferido na ADI 2.390, entre reserva de jurisdição, que pode ser identificada com os princípios da inafastabilidade e da indeclinabilidade da jurisdição, e reserva prévia de jurisdição, que se traduz exatamente nas chamadas cláusulas de reserva jurisdicional (STF, T.P., ADI 2390, julgado em 24.02.2016, p. 97. Disponível em: <http://redir.stf.jus.br/paginadorpub/paginador.jsp?docTP=TP\&docID=11899965>; $\quad$ acesso em 12.02.2020.

${ }^{19}$ Conforme se percebe da leitura de Comparato (1995) e Bulos (2001). O Supremo Tribunal Federal analisou os limites dos poderes investigatórios das Comissões Parlamentares de Inquérito no julgamento do MS 23.452/RJ, em 16.09.1999 (Informativo n. 162 do STF).
}

67 | Revista do Programa de Pós-Graduação em Direito da UFBA, e-issn 2358-4777, v. 30, n. 01, p.55 -77, Jan-Jun 2020 
Nos EUA, a discussão sobre a reserva jurisdicional para acesso a informações sigilosas é encontrada em recorrentes julgados da Suprema Corte sobre a abrangência da 4a e da 5 a emendas à Constituição norte-americana, formando uma jurisprudência que frequentemente tem tangenciado as repercussões decorrentes da evolução da tecnologia ${ }^{20}$.

Embora a Constituição Federal de 1988 tenha previsto, de forma expressa, a inviolabilidade da intimidade e da vida privada como um direito fundamental, limitou-se a estabelecer apenas três hipóteses em que o Poder Judiciário deve sempre ser acionado antes da execução de uma medida invasiva: i) interceptação de comunicações telefônicas; ii) entrada em domicílio (com as exceções que a própria Constituição assinala); e, iii) prisões (exceto a prisão em flagrante). São as denominadas cláusulas de reserva jurisdicional, constantes expressamente no art. 5을 incisos XI, XII e LXI.

Somando-se a estes os incisos XXXV, LIII, LIV e LV do mesmo art. 5o - que consagram os princípios da inafastabilidade da jurisdição, do juiz natural, do devido processo legal, contraditório e ampla defesa -, tem-se o leque de garantias fundamentais do indivíduo correspondentes ao poder do Estado de exercer, com exclusividade, o poderdever da jurisdição.

A rigor, a realização de medidas outras que não se amoldem àquelas hipóteses descritas no art. 5ㅇ, incisos XI, XII e LXI da Constituição Federal de 1988 não estão inseridas no escopo da reserva jurisdicional e, portanto, poderiam ser realizadas pelo Estadoadministração diretamente, sem a intervenção prévia do Poder Judiciário como requisito de validade, bastando, para tanto a existência de autorização conferida pela legislação infraconstitucional.

Os incisos XI, XII e LXI do art. 50 tratam de medidas mais invasivas à liberdade individual, geralmente associadas ao processo penal, daí a opção do constituinte originário em restringir a sua execução aqueles casos em que houvesse uma prévia autorização judicial - reserva jurisdicional - não sendo lícito, em tais casos, que o legislador infraconstitucional autorize a realização direta pelo Estado-administração à míngua de decisão judicial prévia.

Não chega a impressionar a argumentação de que o comando normativo do inciso $X$ do art. 5o da Constituição Federal abarcaria - em estatura constitucional - a reserva jurisdicional, obrigando-se ao Estado recorrer previamente ao Poder Judiciário para obter acesso a dados bancários sigilosos.

$\mathrm{O}$ inciso $\mathrm{X}$ do art. 5o da $\mathrm{CF} / 88$ versa sobre a inviolabilidade da intimidade, da vida privada, da honra e da imagem, e estabelece as consequências decorrentes de sua violação, não fazendo nenhuma menção a dados fiscais ou bancários e nem mesmo a decisão judicial, muito menos a uma hipotética necessidade de prévia autorização do Poder Judiciário. A leitura atenta dos incisos XI, XII e LXI do art. 5o permite verificar que têm estrutura bastante distinta do inciso $X$, eis que lançam mão das expressões "salvo (...) por determinação judicial" (inciso XI), "salvo, no último caso, por ordem judicial" (inciso XII) e "senão (...) por ordem escrita e fundamentada de autoridade judiciária competente" (inciso LXI). Essa clara diferença em relação ao inciso X do art. 5o da CF/88 deve ter sentido e consequências para sua interpretação.

Os tribunais brasileiros, entretanto, interpretando o art. 5o, incisos X e XII, da Constituição $\mathrm{F} / 88$, ampliaram o leque de medidas submetidas à reserva jurisdicional, a

\footnotetext{
${ }^{20}$ Um exemplo: em Carpenter v. United States, a Suprema Corte dos Estados Unidos, em 22.06.2018, decidiu que o acesso aos registros de localização do celular de um suspeito (dados de CSLI, ou cell-site location information, que são gerados a partir do momento em que um terminal se conecta a uma ERB ou antena), com algumas exceções, depende de prévia autorização judicial.
}

68 | Revista do Programa de Pós-Graduação em Direito da UFBA, e-issn 2358-4777, v. 30, n. 01, p.55 -77, Jan-Jun 2020 
exemplo da obtenção de dados bancários e fiscais, em decisões proferidas no âmbito do controle difuso de constitucionalidade, equívoco que contava, inclusive, com o respaldo de decisões proferidas pelo próprio Supremo Tribunal Federal.

Um caso bastante representativo é o julgamento da constitucionalidade do acesso direto pelo Fisco a dados bancários autorizado pelo disposto na Lei $\mathrm{n}$ - 8.021/1990. Esse diploma legal foi aprovado com o intuito de superar o posicionamento do Superior Tribunal de Justiça ${ }^{21}$, que entendia ser obrigatório a existência de processo judicial para o compartilhamento de informações bancárias sigilosas. Nessa linha, dispôs em seu art. 8o que a autoridade fiscal poderia solicitar informações sobre operações realizadas pelo contribuinte em instituições financeiras, inclusive extratos de contas bancárias, não se aplicando, nesta hipótese, o disposto no art. 38 da Lei $n^{\circ}$ 4.595/1964.

A despeito do que passou a dispor o art. 8o Lei no 8.021/1990, o Supremo Tribunal Federal rechaçou, de modo contundente, no julgamento do RE $389.808^{22}$, a possibilidade da Administração Tributária ter acesso aos dados do contribuinte sem prévia autorização judicial, mesmo que existente um processo administrativo, invocando, para tanto, o disposto no art. 5o XII, da Constituição Federal:

SIGILO DE DADOS - AFASTAMENTO. Conforme disposto no inciso XII do artigo 5o da Constituição Federal, a regra é a privacidade quanto à correspondência, às comunicações telegráficas, aos dados e às comunicações, ficando a exceção - a quebra do sigilo submetida ao crivo de órgão equidistante - o Judiciário - e, mesmo assim, para efeito de investigação criminal ou instrução processual penal.

SIGILO DE DADOS BANCÁRIOS - RECEITA FEDERAL. Conflita com a Carta da República norma legal atribuindo à Receita Federal parte na relação jurídico-tributária - o afastamento do sigilo de dados relativos ao contribuinte.

O equívoco dessa interpretação reside em desconsiderar que o inciso XII do art. 5 o trata especificamente do sigilo das comunicações, e não de outro sigilo. Tal equivocada leitura do inciso XII já havia sido identificada anos antes pelo min. Sepúlveda Pertence, no julgamento do MS 21.729/DF ${ }^{23}$, ao pontuar que o âmbito de proteção do inc. XII da CF/88 é a comunicação de dados, e não os dados em si, o que tornaria impossível qualquer investigação administrativa, fosse qual fosse.

A constitucionalidade do tratamento de dados bancários por autoridades do fisco sem a necessidade de prévia autorização judicial foi finalmente reconhecida no julgamento das ADI $2390^{24}$, 2386, 2397 e 2859 e do RE 601.314 (com repercussão geral admitida), em

21 O STJ, à época, entendia que a expressão "processo instaurado" do parágrafo §5o do artigo 38 referiam-se a processo judicial e não administrativo fiscal e, que o sigilo bancário fundamentava-se no artigo 5, incisos X e XI da Constituição Federal, só podendo ser quebrado através de autorização judicial, conforme AgRg nos EDcl no REsp 1135908/SP, Rel. Ministro LUIZ FUX, PRIMEIRA TURMA, julgado em 17/06/2010, DJe 01/07/2010.

22 STF, T.P., RE 389808, Rel. Min. MARCO AURÉLIO, Data de julgamento: 15.12.2010, Data de publicação: DJe-086 10.05.2011.

${ }^{23}$ MS 21729, Relator: Min. MARCO AURÉLIO, Relator p/ Acórdão: Min. NÉRI DA SILVEIRA, Tribunal Pleno, julgado em 05/10/1995, DJ 19-10-2001 PP-00033 EMENT VOL-02048-01 PP-00067 RTJ VOL-00179-01 PP00225.

${ }^{24}$ STF, T.P., ADI 2859/DF, rel. min. Dias Toffoli. Data de julgamento: 24.02.2016, Data de publicação: Dje 21.10.2016

69 | Revista do Programa de Pós-Graduação em Direito da UFBA, e-issn 2358-4777, v. 30, n. 01, p.55 -77, Jan-Jun 2020 
24.02.2016, quando o STF, contando com nova composição, voltou atrás em seu entendimento proclamado no RE 389.808, decidindo, de forma vinculante, o seguinte:

[...] Expressão "do inquérito ou", constante no $\S 40$ do art. 1ำ da Lei Complementar no 105/2001. Acesso ao sigilo bancário nos autos do inquérito policial. Possibilidade. Precedentes. Art. 5o e 6으 da Lei Complementar no 105/2001 e seus decretos regulamentadores. Ausência de quebra de sigilo e de ofensa a direito fundamental. Confluência entre os deveres do contribuinte (o dever fundamental de pagar tributos) e os deveres do Fisco (o dever de bem tributar e fiscalizar). Compromissos internacionais assumidos pelo Brasil em matéria de compartilhamento de informações bancárias. Art. 1ㅇ da Lei Complementar no 104/2001. Ausência de quebra de sigilo. Art. 3으, § 3ㅇ, da LC 105/2001. Informações necessárias à defesa judicial da atuação do Fisco. Constitucionalidade dos preceitos impugnados. ADI no 2.859. Ação que se conhece em parte e, na parte conhecida, é julgada improcedente. $A D I$ no $2.390,2.386,2.397$. Ações conhecidas e julgadas improcedentes. 1. Julgamento conjunto das ADI $n=2.390$, 2.386, 2.397 e 2.859, que têm como núcleo comum de impugnação normas relativas ao fornecimento, pelas instituições financeiras, de informações bancárias de contribuintes à administração tributária. [...] 4. Os artigos 5o e 60 da Lei Complementar no 105/2001 e seus decretos regulamentares (Decretos no 3.724, de 10 de janeiro de 2001, e no 4.489, de 28 de novembro de 2009) consagram, de modo expresso, a permanência do sigilo das informações bancárias obtidas com espeque em seus comandos, não havendo neles autorização para a exposição ou circulação daqueles dados. Trata-se de uma transferência de dados sigilosos de um determinado portador, que tem o dever de sigilo, para outro, que mantém a obrigação de sigilo, permanecendo resguardadas a intimidade e a vida privada do correntista, exatamente como determina o art. 145, § 1으, da Constituição Federal. 5. A ordem constitucional instaurada em 1988 estabeleceu, dentre os objetivos da República Federativa do Brasil, a construção de uma sociedade livre, justa e solidária, a erradicação da pobreza e a marginalização e a redução das desigualdades sociais e regionais. Para tanto, a Carta foi generosa na previsão de direitos individuais, sociais, econômicos e culturais para o cidadão. Ocorre que, correlatos a esses direitos, existem também deveres, cujo atendimento é, também, condição sine qua non para a realização do projeto de sociedade esculpido na Carta Federal. Dentre esses deveres, consta o dever fundamental de pagar tributos, visto que são eles que, majoritariamente, financiam as ações estatais voltadas à concretização dos direitos do cidadão. Nesse quadro, é preciso que se adotem mecanismos efetivos de combate à sonegação fiscal, sendo o instrumento fiscalizatório instituído nos arts. 5ㅇ e 6으 da Lei Complementar no 105/ 2001 de extrema significância nessa tarefa. 6. O Brasil se 
comprometeu, perante o $G 20$ e o Fórum Global sobre Transparência e Intercâmbio de Informações para Fins Tributários (Global Forum on Transparency and Exchange of Information for Tax Purposes), a cumprir os padrões internacionais de transparência e de troca de informações bancárias, estabelecidos com o fito de evitar o descumprimento de normas tributárias, assim como combater práticas criminosas. Não deve o Estado brasileiro prescindir do acesso automático aos dados bancários dos contribuintes por sua administração tributária, sob pena de descumprimento de seus compromissos internacionais. 7. 0 art. 1 ㅇ da Lei Complementar 104/2001, no ponto em que insere o $\S 1$, inciso II, e o $\S 20$ ao art. 198 do CTN, não determina quebra de sigilo, mas transferência de informações sigilosas no âmbito da Administração Pública. Outrossim, a previsão vai ao encontro de outros comandos legais já amplamente consolidados em nosso ordenamento jurídico que permitem o acesso da Administração Pública à relação de bens, renda e patrimônio de determinados indivíduos.

Em suma, a partir do julgamento das ADI 2390, 2386, 2397 e 2859 e do RE 601.314, em 24.02.2016, o STF sacramentou o entendimento de que a Administração Tributária pode ter acesso aos dados bancários independentemente de prévia autorização judicial. Os fundamentos centrais para esse julgamento foram: (a) a ausência de verdadeira "quebra" de sigilo e de ofensa a direito fundamental individual, eis que os dados não perdem seu caráter sigiloso ao serem remetidos às autoridades fazendárias; (b) a necessária harmonização, mediante uma interpretação sistêmica, entre o direito fundamental à intimidade, o dever fundamental do contribuinte de pagar tributos e o dever do Estado de bem tributar e fiscalizar.

Com esse julgamento, como bem acentuou Denise Lucena Cavalcante (2017), é de se esperar que tenha ter sido encerrado esse largo período de jurisprudência oscilante em relação ao sigilo bancário e que o país possa direcionar-se conforme as diretrizes internacionais de transparência fiscal.

Um ponto que passou a merecer acompanhamento próximo é o possível impacto da chamada "Lei Anticrime" - Lei n.o 13.964/2019 - que acrescentou ao Código de Processo Penal o art. 3-B, dispondo competir à novel figura do Juiz das Garantias decidir sobre os requerimentos de afastamento dos sigilos bancário e fiscal, dentre outros, na jurisprudência atual do Supremo Tribunal Federal acerca do acesso direto pelo Fisco aos dados bancários sigilosos.

Antecipando um pouco a argumentação, que precisa ser objeto de análise futura, acredita-se que o STF manterá indene a possibilidade do Fisco acessar as informações bancárias sigilosas, em razão do dever de compartilhamento previsto na Lei Complementar no 105/2001, cuja espécie diferenciada pelo quórum qualificado afastaria a possibilidade de um retrocesso sem que ocorresse uma verdadeira ginástica hermenêutica em detrimento do texto constitucional.

\section{Sigilo Bancário E O Ministério Público: Uma Questão A Ser Resolvida}

Ainda pendente de uma solução mais abrangente, a questão do acesso direto a

71 | Revista do Programa de Pós-Graduação em Direito da UFBA, e-issn 2358-4777, v. 30, n. 01, p.55 -77, Jan-Jun 2020 
dados bancários sigilosos pelo Ministério Público sempre vem à tona nas discussões perante os Tribunais brasileiros, sendo relevante destacar os principais argumentos que permeiam o debate ainda aceso.

As leis orgânicas do Ministério Público brasileiro - i.e., a Lei n.o 8.625/93 (para o Ministério Público dos Estados) e a Lei Complementar n.o 75/93 (para o Ministério Público da União - preveem a possibilidade de acesso, pelo Ministério Público, de quaisquer dados de interesse para uma investigação, cível ou criminal, independentemente de prévia autorização judicial ${ }^{25}$.

Segundo o art. 8o da LC n.o 75/1993 (LOMPU), o Ministério Público da União poderá, nos procedimentos de sua competência e para o exercício de suas atribuições requisitar informações, exames, perícias e documentos de autoridades da Administração Pública direta ou indireta, bem como requisitar informações e documentos a entidades privadas. Dispõe, ainda, que o membro do Ministério Público será civil e criminalmente responsável pelo uso indevido das informações e documentos que requisitar ( $\$ 1$ ) e nenhuma autoridade poderá opor ao Ministério Público, sob qualquer pretexto, a exceção de sigilo, sem prejuízo da subsistência do caráter sigiloso da informação, do registro, do dado ou do documento que lhe seja fornecido ( $\$ 2 \%$ ).

Com relação ao Ministério Público dos Estados, a Lei n. 8.625/1993, em seu art. 26, estatui que, no exercício de suas funções, o MP poderá requisitar informações, exames periciais e documentos de autoridades federais, estaduais e municipais, bem como dos órgãos e entidades da administração direta, indireta ou fundacional, de qualquer dos Poderes da União, dos Estados, do Distrito Federal e dos Municípios; e requisitar informações e documentos a entidades privadas (art. 26, incisos I e II). Ademais, o membro do Ministério Público será pessoalmente responsável pelo uso indevido das informações e documentos que requisitar, inclusive nas hipóteses legais de sigilo (art. 26, §2º).

O STF, contudo, tem sido bastante restritivo quanto à possibilidade de que o Ministério Público tenha acesso a dados bancários sem prévia autorização judicial. É representativo desse entendimento o acórdão do STF proferido no RE $215.301^{26}$, mesmo diante do comando normativo expresso na Lei Complementar no 75/1993 e na Lei n.․․ 8.625/1993:

CONSTITUCIONAL. MINISTÉRIO PÚBLICO. SIGILO BANCÁRIO: QUEBRA. C.F., art. 129, VIII. I. - A norma inscrita no inc. VIII, do art. 129, da C.F., não autoriza ao Ministério Público, sem a interferência da autoridade judiciária, quebrar o sigilo bancário de alguém. Se se tem presente que o sigilo bancário é espécie de direito à privacidade, que a C.F. consagra, art. 50, X, somente autorização expressa da Constituição legitimaria o Ministério Público a promover, diretamente e sem a intervenção da autoridade judiciária, a quebra do sigilo bancário de qualquer pessoa. II. - R.E. não conhecido.

\footnotetext{
${ }^{25}$ Não há previsão semelhante para autoridades policiais, nem no Código de Processo Penal e nem mesmo na lei n.o 12.830/2013 - que dispõe sobre a investigação criminal conduzida pelo delegado de polícia. O máximo que esta lei contém é que "cabe ao delegado de polícia a requisição de perícia, informações, documentos e dados que interessem à apuração dos fatos" (art. 1으, §2으, de lei n.o 12.830/2013).

${ }^{26}$ STF, 2a T., RE 215301, Relator: Min. CARLOS VELLOSO, Data de julgamento: 13.04.1999, Data de publicação: DJ 28.05.1999
}

72 | Revista do Programa de Pós-Graduação em Direito da UFBA, e-issn 2358-4777, v. 30, n. 01, p.55 -77, Jan-Jun 2020 
A restrição ao acesso direto a dados bancários pelo Ministério Público não alcança, por óbvio, as transferências de informações bancárias concernentes a utilização de recursos públicos. Em tais situações, não se exige a prévia autorização judicial, conforme tese fixada em acórdão paradigma proferido pelo Supremo Tribunal Federal, no julgamento do MS $21.729^{27}$ :

Mandado de Segurança. Sigilo bancário. Instituição financeira executora de política creditícia e financeira do Governo Federal. Legitimidade do Ministério Público para requisitar informações e documentos destinados a instruir procedimentos administrativos de sua competência. [...] 4. O poder de investigação do Estado é dirigido a coibir atividades afrontosas à ordem jurídica e a garantia do sigilo bancário não se estende às atividades ilícitas. A ordem jurídica confere explicitamente poderes amplos de investigação ao Ministério Público - art. 129, incisos VI, VIII, da Constituição Federal, e art. 8으, incisos II e IV, e $\S 2$, da Lei Complementar ํㅡ 75/1993. 5. Não cabe ao Banco do Brasil negar, ao Ministério Público, informações sobre nomes de beneficiários de empréstimos concedidos pela instituição, com recursos subsidiados pelo erário federal, sob invocação do sigilo bancário, em se tratando de requisição de informações e documentos para instruir procedimento administrativo instaurado em defesa do patrimônio público. Princípio da publicidade, ut art. 37 da Constituição. [...].

Merece destaque o fim da discussão quanto à possibilidade de compartilhamento de dados bancários sigilosos pela unidade de inteligência financeira brasileira (COAF) e pela autoridade fiscal (RFB) com o Ministério Público, sem prévia autorização judicial, no julgamento do recurso repetitivo RE no $1.055 .941^{2}$, pelo Supremo Tribunal Federal.

Como nos recorda Cunha (2019), o julgamento do caso teve marchas e contramarchas, chegando a contar com uma decisão liminar do min. Relator Dias Toffoli que suspendeu por meses não somente a comunicação de informações da Unidade de inteligência financeira (COAF) ao Ministério Público, mas também milhares de investigações e de processos em todo o Brasil que se baseavam nessas comunicações. Ao cabo desse julgamento, foram fixadas as seguintes teses:

1 - É constitucional o compartilhamento dos relatórios de inteligência financeira da UIF e da íntegra do procedimento fiscalizatório da Receita Federal do Brasil, que define o lançamento do tributo, com os órgãos de persecução penal, para fins criminais, sem a obrigatoriedade de prévia autorização judicial, devendo ser resguardado o sigilo das informações em procedimentos formalmente instaurados e sujeitos a posterior controle jurisdicional.

2 - O compartilhamento pela UIF e pela Receita Federal do Brasil,

\footnotetext{
${ }^{27}$ STF, T.P., MS 21729, Relator: Min. MARCO AURÉLIO, Relator p/Acórdão: Min. NÉRI DA SILVEIRA, Data de julgamento: 05.10.1995, Data de publicação: DJ 19.10.2001.

${ }^{28}$ STF, T. P., RE 1055941 RG, Relator: Min. DIAS TOFFOLI, julgado em 12/04/2018, DJe-083 DIVULG 27-042018 PUBLIC 30-04-2018.
}

73 | Revista do Programa de Pós-Graduação em Direito da UFBA, e-issn 2358-4777, v. 30, n. 01, p.55 -77, Jan-Jun 2020 
referente ao item anterior, deve ser feito unicamente por meio de comunicações formais, com garantia de sigilo, certificação do destinatário e estabelecimento de instrumentos efetivos de apuração e correção de eventuais desvios.

Assim, o RE 1.055.941 foi julgado procedente, por maioria de votos, e restabeleceu sentença condenatória que se amparava em dados compartilhados com Ministério Público pela Receita Federal sem prévia autorização judicial. Resolveu-se, por ora, a questão atinente à possibilidade de compartilhamento, pelas autoridades fiscais e de inteligência financeira, de dados sigilosos - sejam estes dados oriundos de instituições bancárias ou produzidos pela própria autoridade fiscal -, mediante a remessa de tais dados, de ofício, diretamente ao Ministério Público.

Resta em aberto, ainda, a controvérsia relativa à possibilidade de requisição de dados bancários sigilosos às instituições financeiras (não ao fisco ou à UIF) diretamente pelo Ministério Público. No quadro atual, como dito, o que se tem sedimentado é a impossibilidade do acesso direto, salvo quando se tratar de recursos públicos, entendimento fixado no controle difuso de constitucionalidade, sem efeitos vinculantes.

Nesta perspectiva, calha sublinhar que, no julgamento das ADI 2390, 2386, 2397 e 2859 e do RE 601.314, em 2016, o STF não identificou a existência de verdadeira reserva jurisdicional para o acesso a dados bancários, reputando, destarte, constitucional a Lei Complementar n. 105/2001 nas disposições em que autoriza o seu compartilhamento direto ao Fisco. Com base no mesmo argumento, sendo coerente o STF, decidirá também pela constitucionalidade das disposições da Lei n.o 8.625/1993 e da Lei Complementar n.으 75/1993, nos pontos em que versam sobre a requisição de dados - inclusive bancários - e sobre a impossibilidade de recusa ao fornecimento desses dados, por parte das instituições financeiras, ao argumento de que se trata de dados sigilosos.

De qualquer sorte, certamente não se poderá afirmar que o Ministério Público tem poderes para dispor, sponte propria, do caráter sigiloso dos dados recebidos, até porque a entrega desses dados não se confunde com uma "quebra" de sigilo, devendo ser compreendido, sim, como um compartilhamento do dever de preservação do sigilo. Abusos podem e devem ser coibidos, mediante controle judicial concomitante ou posterior $^{29}$. Outrossim, eventual decisão do Supremo Tribunal Federal sobre o tema deverá cotejar as leis orgânicas do Ministério Público brasileiro com as alterações do Código de Processo Penal promovidas pela lei n. 13.964/2019 (lei "anticrime"), em especial o rol de atribuiç̧̃̃es do nominado Juiz das Garantias (art. 3-B, inciso XI, alíneas b e d) - cuja eficácia foi suspensa em janeiro de 2020, por decisão do min. Relator nas ADI 6.298, 6.299, 6.300 e 6305.

\section{Conclusões}

Buscou-se, no presente artigo, expor o conceito do sigilo bancário e de suas teorias fundantes, apresentar um histórico sobre a evolução do tema no ordenamento jurídico e na jurisprudência brasileira, discorrer sobre a controvérsia acerca da necessidade

\footnotetext{
${ }^{29}$ É a conclusão a que chega, também, CAVALCANTI, José Robalinho: Sigilo bancário no Brasil, dualidade e globalização: duas propostas para reunificação e retomada da coerência perante o texto constitucional. In: CALABRICH, Bruno; FISCHER, Douglas; PELELLA, Eduardo. Garantismo penal integral: questões penais e processuais, criminalidade moderna e a aplicação do modelo garantista no Brasil. São Paulo: Verbo Jurídico, 4. ed. 2017. pp. 297-321.
}

74 | Revista do Programa de Pós-Graduação em Direito da UFBA, e-issn 2358-4777, v. 30, n. 01, p.55-77, Jan-Jun 2020 
de prévia autorização judicial para o acesso a dados bancários por parte de autoridades fazendárias e do Ministério Público, tal qual espelhada em julgados do Supremo Tribunal Federal.

Apontou-se que o sigilo bancário alcança as operações ativas e passivas e os serviços das instituições financeiras (aplicações, transferências, depósitos e etc), não estando submetidos a este segredo os dados cadastrais bancários (número da contacorrente, nome completo, documentação pessoal, número de telefone e endereços físicos e eletrônicos do respectivo titular, RG e CPF).

Demonstrou-se que o tratamento dispensado ao tema do sigilo bancário não é unívoco, seja no direito estrangeiro, seja, ao longo do tempo, no próprio direito brasileiro, embora exista uma preocupação atual por parte dos países que integram a OCDE com a possibilidade de que contribuintes ocultem atividades ilegais e escapem da tributação, provocando consequências danosas, local e internacionalmente, em situações de abuso do direito ao sigilo bancário.

A evolução do tratamento jurídico conferido ao sigilo bancário no Brasil segue uma trilha que passa pela atribuição de segredo absoluto a um sigilo moderado, sob o manto normativo da Constituição Federal de 1988 e da Lei Complementar no 105/2001.

O compartilhamento de informações bancárias sigilosas para o Estadoadministração não está inserido no escopo da reserva jurisdicional e, portanto, pode deve - ser realizado, diretamente, sem a intervenção prévia do Poder Judiciário como requisito de validade, tendo em vista as disposições normativas constantes na legislação infraconstitucional.

Destacou-se que o julgamento das ADI 2390, 2386, 2397 e 2859 e do RE 601.314, em 24.02.2016, representou um importante marco na estabilização de nossa jurisprudência a respeito da constitucionalidade do compartilhamento de dados bancários e do dever de manutenção de seu caráter sigiloso pelo agente público responsável, tendo o STF então decidido que a Administração Tributária, respeitados certos requisitos previstos em lei, pode ter acesso aos dados bancários do contribuinte independentemente de prévia autorização judicial.

O julgamento do Recurso Extraordinário (RE) 1.055.941, em 04.12.2019, com repercussão geral, foi o passo subsequente e necessário à consolidação da constitucionalidade da legislação pátria sobre o tema, tendo o STF chancelado o compartilhamento de dados bancários feito de ofício, por autoridades fazendárias e de inteligência financeira, com o Ministério Público - a quem também tocará o dever de preservação do sigilo dos dados recebidos.

Ainda não se tem a manifestação definitiva da Corte Constitucional brasileira quanto à possibilidade de compartilhamento de dados com o Ministério Público e com outras autoridades relacionadas à persecução penal, por iniciativa própria, de modo previamente dependente, ou não, de autorização judicial. Os paradigmas firmados em suas recentes decisões e os vetores para os quais aponta o histórico das inovações legislativas sobre o tema fornecem subsídios relevantes para tanto.

A superação da apontada controvérsia é de grande relevância para que se confira maior segurança a cidadãos e a autoridades públicas, de modo a tutelar, a um só tempo, tanto os direitos fundamentais dos titulares dos dados bancários quanto o interesse público que deve fundamentar o eventual acesso a tais dados pelo Estado. 
9 Referências

ABRÃO, Nélson. Direito bancário. São Paulo: Saraiva, 2001.

BALEEIRO, Aliomar. Direito tributário brasileiro. 2a Ed. Rio de Janeiro: Forense, 1970.

BALTAZAR JUNIOR, José Paulo. Sigilo bancário e privacidade. Porto Alegre: Livraria do Advogado, 2005.

BULOS, Uadi Lammêgo. Comissões parlamentares de inquérito: técnica e prática. São Paulo: Saraiva, 2001.

CANOTILHO, J. J. Gomes. Direito constitucional e teoria da Constituição. 7. ed. Coimbra: Almedina, 2003.

CALABRICH, Bruno. Investigação Criminal pelo Ministério Público: limites e fundamentos constitucionais. São Paulo: RT, 2007.

CAVALCANTE, Denise Lucena. Sigilo bancário: após 15 anos o STF bate o martelo. In Administração Pública e Tributação no Brasil. Rio de Janeiro: Lumen Juris. 2017. p. 03-19.

CAVALCANTE, Marcos Torres. O direito ao sigilo bancário e sua relativização frente à administração tributária brasileira. 2007. 184 f. Dissertação (Mestrado em Ciência Jurídica) - Universidade Federal de Alagoas, Maceió, 2007.

CAVALCANTI, José Robalinho: Sigilo bancário no Brasil, dualidade e globalização: duas propostas para reunificação e retomada da coerência perante o texto constitucional. In: CALABRICH, Bruno; FISCHER, Douglas; PELELLA, Eduardo. Garantismo penal integral: questões penais e processuais, criminalidade moderna e a aplicação do modelo garantista no Brasil. São Paulo: Verbo Jurídico, 4. ed. 2017. pp. 297-321.

CHINEN, Roberto Massao. Sigilo bancário e o fisco: liberdade ou igualdade? Curitiba: Juruá, 2005.

COMPARATO. Fábio Konder. Comissão parlamentar de inquérito (Pareceres). Revista Trimestral de Direito Público, n. 10, São Paulo,Malheiros, 1995.

CORREIA, Thaíse Francelino; SANTANA, Hadassah Laís de Souza; BORGES, Antônio de Moura. A mudança de paradigma do direito tributário quanto ao sigilo bancário. Revista Juridica, [S.I.], v. 3, n. 44, p. 568 - 596, fev. 2017. ISSN 2316-753X. Disponível em: <http://revista.unicuritiba.edu.br/index.php/RevJur/article/view/1880>. Acesso em: 15 fev. 2020. doi: http://dx.doi.org/10.21902/revistajur.2316-753X.v3i44.1880.

COVELLO, Sérgio Carlos. O sigilo bancário. 2. ed. São Paulo: LEUD, 2001. 
CUNHA, Rogério Sanches. STF fixa tese de repercussão geral para autorizar compartilhamento de dados bancários e fiscais sem autorização judicial. Disponível em <https://meusitejuridico.editorajuspodivm.com.br/2019/12/05/stf-fixa-tese-derepercussao-geral-para-autorizar-compartilhamento-de-dados-bancarios-e-fiscais-semautorizacao-judicial/>. Acesso em 16.02.2020.

DAVID, René. Os grandes sistemas do direito contemporâneo. Tradução: Hermínio A Carvalho. São Paulo: Martins Fontes, 1986.

FARHAT, Raymond. Le secret bancaire: étude de droit comparé (France, Suisse, Liban). Paris: Librairie Générale de Droit et de Jurisprudence, 1980.

FLORES, Melina Castro Montoya. Sigilo bancário e reserva de jurisdição no âmbito das investigações criminais. Disponível em:

$<$ https://politica.estadao.com.br/blogs/fausto-macedo/sigilo-bancario-e-reserva-dejurisdicao-no-ambito-das-investigacoes-criminais/> Acesso em: 14 fev. 2020.

GRAMSTRUP, Erik Frederico. Sigilo fiscal e bancário - Fundamentos normativos e principiológicos da quebra. R. bras. Est. const. - RBEC. Belo Horizonte, ano 8, n. 28, p. 95117, jan./abr. 2014.

HABER Neto, Michel. Transparência Fiscal \& Sigilo Tributário. Curitiba: Juruá, 2018. LABANCA, Jorge. El secreto bancario y otros estudios. Buenos Aires, Abeledo-Perrot, 1968. LAKS. Larissa Rodrigues. Liberdade de informação e privacidade: o debate sobre a constitucionalidade da transferência do sigilo bancário à administração tributária. Revista do Direito Público, Londrina, v. 12, n. 1, p.86-118, abr. 2017.

MALAGARRICA, Juan Carlos. El secreto bancario. Buenos Aires: Abeledo-Perrot, 1970. MARTINS, Ives Gandra da Silva. Sigilo Bancário e Tributario. In: C. ALTAMIRANO, Alejandro et al. III Colóquio Internacional de Direito Tributário - III Coloquio Internacional de Derecho Tributario. Buenos Aires: La Ley e IOB, 2001.

OLIVEIRA, Vicente Kleber Melo de. Direito Tributário. Belo Horizonte: Editora Del Rey, 2001. WALD, Arnnoldo. Sigilo bancário e os direitos fundamentais. Cadernos de Direito Tributário e Finanças Públicas. São Paulo. v.6. n.22. 1998.

77 | Revista do Programa de Pós-Graduação em Direito da UFBA, e-issn 2358-4777, v. 30, n. 01, p.55 -77, Jan-Jun 2020 